\title{
RARE WATERFOWL IN SOUTHERN MANITOBA, 1977
}

RICHARD W. KNAPTON, 337 - 99 Dalhousie Drive, Winnipeg, Manitoba R3T 3M2; RUDOLF F. KOES, 135 Rossmere Crescent, Winnipeg, Manitoba R2K 0C1 and PETER TAYLOR, P.O. Box 597, Pinawa, Manitoba R0E 1L0

Twelve species of waterfowl are considered to occur irregularly in southern Manitoba. ${ }^{2}$ Of these, the Garganey is an exotic, ${ }^{4}$ the Common Eider has not been recorded in southern Manitoba since 1911², and the Ross' Goose has been reported with increasing frequency in recent years to indicate that it is a regular migrant through southern Manitoba. All the remaining species were reported in 1977, some in surprisingly high numbers. The following annotated list gives details of the various sightings.

TRUMPETER SWAN. Two were sighted at Oak Lake on October 31, and November 1 , by D. R. M. Hatch. The birds, both adults, were heard trumpeting and were seen with a flock of Whistling Swans

BRANT. A. Lindsay reported two Brant, which were associating with Canada Geese, on May 8, at Oak Hammock Marsh, and one was subsequently seen there on May 10, by A. MacLean.

CINNAMON TEAL. A male was observed and photographed at Oak Hammock Marsh by many observers after its initial discovery on May 7 , by G. Holland. It was last seen on June 4 . A male was also observed at Libau by J. Christie on October 6.

EUROPEAN WIGEON. A male was seen in the company of a female wigeon on the Red River at Aubigny on April 16, by $C$. and N. Dixon. The specific identity of the female was not determined. What was possibly the same male was seen at Breezy Point, north of Selkirk, on April 19, by D. R. M. Hatch. On October 2, G. Holland and G. Grieef saw a male in a flock of American Wigeon at Oak Hammock Marsh.

BARROW'S GOLDENEYE. A pair wa seen with Common Goldeneye alon: the Red River south of Lockport by $\mathrm{L}$ and J. Holmes on April 17, and what was likely the same pair was seen a Breezy Point on April 19, by D. R. M Hatch. On October 18, A. MacLean reported a female Barrow's Coldeneyt at Clear Lake, Wasagaming. These sightings raise the number of records of this species in southern Manitoba since 1900 to at least eight involving 11 or more individuals. ${ }^{3}$

OLDSQUAW. Possibly a regula migrant in southern Manitoba. ${ }^{6}$ At least one was seen along the Assiniboine River diversion near Portage la Prairie on April 17, by $B$ Batt and R. E. Jones.

HARLEQUIN DUCK. A female o immature was seen at Victoria Beach on November 12, 13 and 19, by numerous observers after its initia discovery by Peter Taylor. The bir associated with two female Buf fleheads and it allowed close ap proach $(15 \mathrm{~m})$ as it dived and loafec close inshore. This is probably the seventh record for souther Manitoba. ${ }^{5}$

BLACK SCOTER. This normally scarce species was recorded on three oc casions; one at the Pinawa Sewage Lagoons on November 5, (Peter Taylor), two at Oak Lake on November 12, (D. R. M. Hatch), and four at Victoria Beach between November 12 and 19, (many observers). All birds were in female or immature plumage. 
